\title{
PENGARUH PEMBERIAN ANGKAK (RED YEAST RICE) TERHADAP KADAR KOLESTEROL LDL DAN HDL PADA WANITA DISLIPIDEMIA
}

\author{
Aminatis Saniah, Tatik Mulyati*) \\ Program Studi Ilmu Gizi Fakultas Kedokteran Universitas Diponegoro \\ Jl.Dr.Sutomo No.18, Semarang, Telp (024) 8453708, Email : gizifk@ undip.ac.id
}

\begin{abstract}
Background : dyslipidemia have been shown to be one of the factors associated with cardiovascular disease. Monacolin K contained in angkak (Red Yeast Rice) can reduced LDL cholesterol and increased HDL levels by inhibited $H M G$-CoA reductase, resulted in the formation of cholesterol will inhibited.

Method : This research was true experimental study with pre-post control group design. Subjects were women dyslipidemia with LDL cholesterol level > $120 \mathrm{mg} / \mathrm{dl}$ and HDL cholesterol $<50 \mathrm{mg} /$ dl, classified into 2 groups, control group given a placebo and the treatment group consumed $4.8 \mathrm{~g} /$ day. Intervention was done for 14 days. Blood was collected after an overnight fast. Serum LDL cholesterol level was measured with calculation method and HDL cholesterol level use phosphotungstic precipitation method. Shapiro-Wilk was used to analyze normality of the data. The statistical analyze include independent t-test and Mann-Whitney.

Results : There was not influenced of red yeast rice (RYR) $4.8 \mathrm{~g} /$ day at LDL level and HDL before and after interventions $152.91 \mathrm{mg} / \mathrm{dl}, 163.73 \mathrm{mg} / \mathrm{dl}$ and $43.11 \mathrm{mg} / \mathrm{dl}, 44.05 \mathrm{mg} / \mathrm{dl}$. There was not differenced of reduced LDL level and increased HDL level before and after the study.

Conclusion : Consumption of RYR $4.8 \mathrm{~g}$ /day in 14 days had no effect on LDL cholesterol level and HDL in women with dyslipidemia. There is no significantly difference of $L D L$ and $H D L$ between the two groups.

Keywords : red yeast rice (RYR); LDL cholesterol level; HDL cholesterol level; dyslipidemia.
\end{abstract}

\section{ABSTRAK}

Latar Belakang: Dislipidemia merupakan salah satu faktor risiko terjadinya penyakit jantung dan pembuluh darah. Monakolin $K$ yang terdapat pada angkak (Red Yeast Rice) dapat menurunkan kadar kolesterol LDL dan meningkatkan kadar HDL dengan cara menghambat kerja HMG-KoA reduktase sehingga pembentukan kolesterol akan terhambat.

Metode: Jenis penelitian adalah true experimental dengan rancangan pre-post control group design. Subyek adalah wanita dislipidemia dengan kadar kolesterol LDL >120 mg/dl dan HDL < 50mg/dl, dibagi menjadi 2 kelompok, yaitu kelompok kontrol yang diberi placebo dan kelompok perlakuan yang diberi angkak 4.8 g/hari. Intervensi dilakuan selama 14 hari. Metode phosphotungstic precipitation digunakan untuk menganalisis kadar kolestrol HDL dan metode perhitungan digunakan untuk menganalisis kadar LDL, darah diambil setelah subyek berpuasa selama 10 jam. Uji normalitas menggunakan Shapiro-Wilk. Analisis statistik menggunakan uji dependent $t$-test, Wilcoxon, independent t-test dan Mann-Whitney.

Hasil : Tidak terdapat pengaruh pemberian angkak (RYR) 4.8 g/hari pada kadar LDL dan HDL sebelum dan sesudah intervensi $152.91 \mathrm{mg} / \mathrm{dl}$, $163.73 \mathrm{mg} / \mathrm{dl}$ dan $43.11 \mathrm{mg} / \mathrm{dl}$, $44.05 \mathrm{mg} / \mathrm{dl}$. Secara statistik menunjukkan tidak ada perbedaan penurunan kadar LDL dan peningkatan kadar HDL sebelum dan sesudah penelitian.

Kesimpulan : Konsumsi angkak dengan dosis 4.8 g/hari selama 14 hari tidak berpengaruh terhadap kadar kolesterol LDL dan HDL pada wanita dislipidemia. Tidak ada perbedaan kadar kolesterol LDL dan HDL antara kelompok kontrol dan perlakuan.

Kata kunci: angkak (red yeast rice); koleterol LDL; kolesterol HDL; dislipidemia

\section{PENDAHULUAN}

Dislipidemia merupakan salah satu faktor terjadinya penyakit jantung dan pembuluh darah. $^{1,2,3}$ Profil Kesehatan Jawa Tengah tahun 2011 melaporkan dari total 1.409 .857 kasus penyakit tidak menular terdapat $62.43 \%$ atau 880.193 kasus penyakit jantung dan pembuluh darah. Rekapitulasi data kesakitan tahun 2012 Dinas Kesehatan Kota Semarang melaporkan terdapat 8.462 kasus penyakit jantung dan pembuluh darah. $^{4,5}$

Faktor risiko yang diduga dapat mempengaruhi terjadinya dislipidemia adalah kelebihan asupan lemak jenuh. Asupan lemak yang berlebih dapat mempengaruhi proses biosentesis kolesterol . 2,3 Monakolin K dapat menurunkan risiko penyakit jantung dan pembuluh darah melalui proses biosintesis kolesterol, yaitu dengan cara menghambat enzim HMG-KoA (3-hidroksi-3-

${ }^{*}$ Penulis Penanggungjawab 
metilglutaril-KoA) reduktase dalam hati. Salah satu makanan fungsional yang mengandung Monakolin K adalah angkak (Red yeast rice). ${ }^{6}$

Pemberian suplementasi kapsul angkak (RYR) dengan dosis 3,6 g/hari selama 24 minggu diketahui dapat menurunkan kadar kolesterol LDL sebesar 21,3\% dan meningkatkan kadar HDL sebesar $8,6 \%$. $^{7}$ Pemberian ekstrak angkak pada tikus jantan galur wistar yang telah diberi pakan tinggi lemak dengan dosis $20 \mathrm{mg} / 200 \mathrm{BB}$ dan 40 $\mathrm{mg} / 200 \mathrm{BB}$ per hari selama 21 hari meningkatkan kadar HDL berturut-turut menjadi $42,42 \mathrm{mg} / \mathrm{dl}$ dan $48,24 \mathrm{mg} / \mathrm{dl}^{8}$

Angkak (Red Yeast Rice/RYR) masuk kedalam kategori makanan fungsional yang dihasilkan dari fermentasi beras dengan khamir Monascus purpureus. $^{7}$ Senyawa bioaktif yang terdapat dalam angkak adalah Monakolin K yang memiliki kesamaan mekanisme dengan obat golongan statin yaitu dapat menghambat biosintesis kolesterol dalam hati. Monakolin K bekerja dengan cara menghambat enzim HMGKoA reduktase yang akan mencegah pembentukan mevalonat sehingga isoprene yang dihasilkan mevalonat akan menurun dan pembentukan squalen juga akan menurun, serta kadar kolesterol intrasel menurun. ${ }^{8,9,10}$

Sebuah study cross-sectional yang dilakukan pada beberapa suku di Indonesia menunjukkan nilai rata-rata kadar kolesterol LDL dan HDL pada pria dan wanita suku jawa dengan umur $>40$ tahun hampir sama yaitu $>120 \mathrm{mg} / \mathrm{dl}$ dan $<50 \mathrm{mg} / \mathrm{dl}^{11}$

Penelitian mengenai pengaruh ekstrak angkak (RYR) pada hewan coba dengan dosis 20 $\mathrm{mg} / 200 \mathrm{BB}$ dan $40 \mathrm{mg} / 200 \mathrm{BB}$ selama 21 hari di Indonesia dan suplementasi angkak pada pasien dislipidemia dosis 3,6 g/hari selama 24 minggu telah dilakukan, namun penelitian tentang pemberian seduhan angkak pada wanita dislipidemia dengan dosis 4,8 g/hari selama 14 hari di Indonesia belum dilakukan. Hal inilah yang mendasari dilakukannya penelitian ini. Pemilihan subyek penelitian di lingkungan kantor Badan Pusat Statistik (BPS) Jawa Tengah, kantor Badan Pusat Perijinan Terpadu Kota Semarang, Badan Pembanguan Daerah Kota Semarang dan karyawati yayasan Pangudi Luhur Semarang dianggap dapat mewakili populasi dengan aktivitas fisik rendah.

\section{METODE}

Penelitian ini merupakan penelitan true experimental dengan rancangan pre-post control group design. Variabel terikat dalam penelitian ini adalah kadar kolesterol LDL dan HDL penderita dislipidemia, sedangkan variabel bebas adalah dosis angkak (RYR).

Subyek penelitian karyawati kantor Badan Pusat Statistik Jawa Tengah, kantor Badan Perencanaan Pembangunan Daerah Semarang, kantor BPPT Semarang dan karyawati Yayasan Pangudi Luhur Semarang. Kriteria inklusi memiliki kadar kolesterol LDL $>120 \mathrm{mg} / \mathrm{dl}$ dan kadar kolesterol HDL $<50 \mathrm{mg} / \mathrm{dl}$, belum mengalami menopause, bersedia menjadi subyek penelitian, tidak sedang mengkonsumsi obat antihiperlipidemia dan tidak dalam keadaan sakit atau perawatan dokter, serta tidak dalam keadaan hamil atau menyusui. Perhitungan subyek penelitan menggunakan rumus uji hipotesis terhadap rerata dua populasi independen dan dibutuhkan sebanyak 36 subyek.

Penentuan subyek penelitian menggunakan metode consecutive sampling. Sebanyak 102 orang bersedia diambil darahnya untuk proses skrining awal dan diperoleh sebanyak 36 orang yang memenuhi kriteria inklusi untuk menjadi subyek penelitian. Subyek dibagi menjadi 2 kelompok dengan metode simple random sampling, yang terdiri atas satu kelompok kontrol dan satu kelompok perlakuan, masing-masing kelompok terdiri atas 18 subyek. Kelompok kontrol diberikan placebo yaitu filtrat beras yang disangrai 4,8 $\mathrm{g} /$ hari dengan sirup rendah kalori $25 \mathrm{ml} /$ kemasan dan kelompok perlakuan diberikan filtrat angkak (RYR) 4,8 g/hari dengan sirup rendah kalori 25 $\mathrm{ml} /$ kemasan.

Pembuatan angkak dilakukan dengan cara penimbangan $4.8 \mathrm{~g}$ terlebih dahulu dan ditambahkan $200 \mathrm{ml}$ air kemudian dipanaskan selama \pm 15 menit, setelah mendidih rebusan angkak diangkat dan dilakukan penyaringan serta pendinginan selama \pm 10 menit. Selanjutnya angkak dikemas menggunakan gelas disposable dan ditambahkan sirup rendah kalori 25 $\mathrm{ml} /$ kemasan. Penutupan kemasan menggunakan alat cup sealer dengan suhu $140^{\circ} \mathrm{C}$. Placebo dibuat dengan proses yang sama dengan pembuatan angkak.

Pemberian angkak (RYR) dan placebo dilakukan selama 14 hari. asupan sehari-hari baik untuk kelompok perlakuan maupun kontrol tidak dikontrol dan dibiarkan sebagaimana biasa. Pencatatan asupan makan dilakukan menggunakan 7 x recall 24 jam sebelum sebanyak 2 kali dan selama intervensi sebanyak 5 kali dilakukan pada weekdays dan weekend. Sementara kepatuhan 
mengkonsumsi angkak dan placebo dikontrol dengan menggunakan formulir daya terima. Tidak ada subyek yang drop out dalam penelitian ini.

Kadar kolesterol LDL dan HDL dianalisis dengan pemeriksaan laboratorium menggunakan metode perhitungan dan phosphotungstic parcipitation. Darah diambil oleh petugas laboratorium setelah subyek berpuasa selama \pm 10 jam. Sementara data asupan makan subyek dianalisis menggunakan program nutrisurvey 2005.

Karakteristik subyek dianalisis menggunakan analisis deskriptif. Uji normalitas menggunakan uji Shapiro-Wilk. Uji dependent ttest digunakan untuk menganalisis kadar kolesterol LDL sebelum dan sesudah perlakuan, asupan protein, karbohidrat, dan serat karena data berdistribusi normal. Non parametrik Wilcoxon digunakan untuk menganalisis kadar HDL sebelum dan sesudah perlakuan, asupan energi, lemak dan kolesterol karena data berdistribusi tidak normal. Uji independent t-test digunakan untuk melihat IMT dan kadar LDL sebelum intervensi karena data berdistribusi normal. Data yang tidak normal diuji dengan uji Mann-Whitney yaitu kadar HDL sebelum intervensi.

\section{HASIL PENELITIAN \\ Karakteristik subyek}

Karakteristik subyek terdiri dari gambaran umur dan status gizi subyek sebelum penelitian disajikan dalam tabel 1. Seluruh subyek adalah wanita dengan usia > 20 tahun dan belum mengalami menopause.

Tabel 1. Karakteristik subyek

\begin{tabular}{|c|c|c|c|c|c|c|c|}
\hline \multirow[t]{2}{*}{ Karakteristik subyek } & \multirow[t]{2}{*}{ Mean \pm SD } & \multicolumn{2}{|c|}{$\begin{array}{c}\text { Kontrol } \\
(n=18)\end{array}$} & \multirow[t]{2}{*}{ Mean \pm SD } & \multicolumn{2}{|c|}{$\begin{array}{c}\text { Perlakuan } \\
(\mathrm{n}=18)\end{array}$} & \multirow[t]{2}{*}{$\mathbf{P}$} \\
\hline & & $\mathbf{n}$ & $\%$ & & $\mathbf{n}$ & $\%$ & \\
\hline \multicolumn{8}{|l|}{ Umur } \\
\hline 20-29 tahun & & 1 & $5.6 \%$ & & - & - & \\
\hline 30-39 tahun & $42.66 \pm 7.14$ & 3 & $16.7 \%$ & $45.87 \pm 6.45$ & 3 & $16.7 \%$ & $0.155^{1}$ \\
\hline 40-49 tahun & & 12 & $66.7 \%$ & & 10 & $55.6 \%$ & \\
\hline 50-59 tahun & & 2 & $11.1 \%$ & & 5 & $27.8 \%$ & \\
\hline \multicolumn{8}{|l|}{ Status Gizi } \\
\hline Normal $\left(18,5-22,9 \mathrm{~kg} / \mathrm{m}^{2}\right)$ & & 7 & $38.9 \%$ & & 3 & $16.7 \%$ & \\
\hline Overweight $\left(23-24,9 \mathrm{~kg} / \mathrm{m}^{2}\right)$ & $23.94 \pm 2.92$ & 4 & $22.2 \%$ & $26.38 \pm 4.02$ & 4 & $22.2 \%$ & $0.040^{1}$ \\
\hline Obesitas $\left(\geq 25 \mathrm{~kg} / \mathrm{m}^{2}\right)$ & & 7 & $38.9 \%$ & & 11 & $61.1 \%$ & \\
\hline Kolesterol LDL & $148.03 \pm 23.08$ & & & $152.91 \pm 22.94$ & & & $0.530^{1}$ \\
\hline Kolesterol HDL & $46.55 \pm 4.87$ & & & $43.11 \pm 7.14$ & & & $0.142^{2}$ \\
\hline
\end{tabular}

${ }^{1}$ uji beda independent t-test

${ }^{2}$ uji beda mann-whitney

Sebagian besar subyek dalam penelitian ini baik kontrol (66.79\%) maupun perlakuan $(55.6 \%)$ berada pada kelompok umur 40-49 tahun dan memiliki kategori status gizi overweight dan obesitas. Hasil uji beda menunjukkan tidak terdapat perbedaan umur dan kadar kolesterol LDL dan HDL pada kelompok kontrol dan perlakuan $(\mathrm{p}>0.05)$. Sedangkan pada status gizi terdapat perbedaan bermakna terhadap kelompok kontrol dan perlakuan $(\mathrm{p}<0.05)$

Perbedaan dan perubahan asupan makan sebelum dan selama intervensi

Perbedaan dan perubahan asupan makan subyek sebelum dan selama intervensi antara kedua kelompok disajikan dalam tabel 2.

Tabel 2. Perbedaan dan perubahan asupan sebelum dan sesudah intervensi

\begin{tabular}{llllll}
\hline Asupan & $\begin{array}{l}\text { Perlakuan } \\
(\mathbf{n = 1 8}) \\
\text { Mean } \pm \text { SD }\end{array}$ & $\begin{array}{l}\text { \% } \\
\text { kecukupan }\end{array}$ & $\begin{array}{l}\text { Kontrol } \\
(\mathbf{n = 1 8}) \\
\text { Mean } \pm \text { SD }\end{array}$ & $\begin{array}{l}\text { \% } \\
\text { kecukupan** }\end{array}$ & p \\
\hline Energi pre & $1725.18 \pm 421.10$ & $95.84 \%$ & $1896.46 \pm 701.0$ & $105.35 \%$ & \\
Energi post & $1697.95 \pm 410.74$ & $94.33 \%$ & 8 & $103.31 \%$ & \\
\hline
\end{tabular}




\begin{tabular}{llllll}
\hline$\Delta$ energi & $-27.23 \pm 541.24$ & & $1859.60 \pm 627.5$ & & $0.955^{3}$ \\
$\mathbf{p}$ & $0.983^{2}$ & & 6 & \\
& & & $-36.86 \pm 478.79$ & & \\
& & & $0.723^{2}$ & & \\
\hline Protein pre & $66.36 \pm 26.47$ & $98.31 \%$ & $67.20 \pm 26.28$ & $99.55 \%$ & \\
Protein post & $58.21 \pm 15.96$ & $86.23 \%$ & $66.96 \pm 26.22$ & $99.20 \%$ & \\
$\Delta$ protein & $-8.14 \pm 28.72$ & & $-0.24 \pm 21.86$ & & $0.359^{3}$ \\
$\mathbf{p}$ & $0.245^{1}$ & & $0.963^{1}$ & & \\
\hline Karbohidrat & $226.19 \pm 58.36$ & $91.38 \%$ & $261.95 \pm 97.66$ & $105.83 \%$ & \\
pre & $236.23 \pm 49.51$ & $95.44 \%$ & $251.24 \pm 68.65$ & $101.51 \%$ & \multirow{2}{*}{$0.448^{3}$} \\
Karbohidrat & $10.03 \pm 90.67$ & & $-10.71 \pm 69.96$ & & \\
post & $0.645^{1}$ & & $0.525^{1}$ & & \\
$\Delta$ karbohidrat & & & & & \\
p & & & & & \\
\hline Lemak pre & $62.43 \pm 32.08$ & $104.05 \%$ & $67.01 \pm 37.98$ & $111.68 \%$ & \\
Lemak post & $58.62 \pm 23.46$ & $97.70 \%$ & $68.67 \pm 32.99$ & $114.45 \%$ & \\
$\Delta$ lemak & $-3.81 \pm 39.60$ & & $1.66 \pm 27.18$ & & \\
p & $0.913^{2}$ & & $0.670^{2}$ & & \\
\hline Cholesterol pre & $267.36 \pm 281.65$ & $133.68 \%$ & $319.41 \pm 204.03$ & $159.70 \%$ & \\
Cholesterol & $225.36 \pm 97.51$ & $112.68 \%$ & $241.06 \pm 192.10$ & $120.53 \%$ & \\
post & $-42.00 \pm 326.34$ & & $-78.34 \pm 202.20$ & & \\
$\Delta$ cholesterol & $0.446^{2}$ & & $0.049^{2}$ & & \\
p & & & & & \\
\hline Serat pre & $11.37 \pm 4.6$ & $45.48 \%$ & $10.97 \pm 4.10$ & $43.88 \%$ & \\
Serat post & $13.25 \pm 54$ & $53.00 \%$ & $10.76 \pm 3.1$ & $43.04 \%$ & \\
$\Delta$ serat & $1.88 \pm 7.70$ & & $-0.21 \pm 2.85$ & & \\
p & $0.315^{1}$ & & $0.759^{1}$ & & \\
\hline
\end{tabular}

${ }^{1}$ uji paired sample t- test, ${ }^{2}$ uji wilcoxon, ${ }^{3}$ uji independent t- test, ${ }^{4}$ uji mann-whitney, ${ }^{*}$ AKG 2004 dan rekomendasi asupan untuk dislipidemia

Berdasarkan tabel 2, diketahui bahwa tidak terdapat perbedaan asupan energi, protein, karbohidrat, lemak dan serat sebelum dan sesudah intervensi antara kedua kelompok $(p>0.05)$. Pada kolesterol terdapat perbedaan pada kelompok kontrol $(\mathrm{p}<0.05)$ tetapi pada kelompok perlakuan tidak terdapat perbedaan. Tidak terdapat perubahan asupan antara kedua kelompok ( $p>0.05$ ).

Perbedaan kategori Indek Massa Tubuh (IMT) sebelum dan sesudah intervensi

Perbedaan kategori IMT sebelum dan sesudah intervensi disajikan pada grafik 1 .

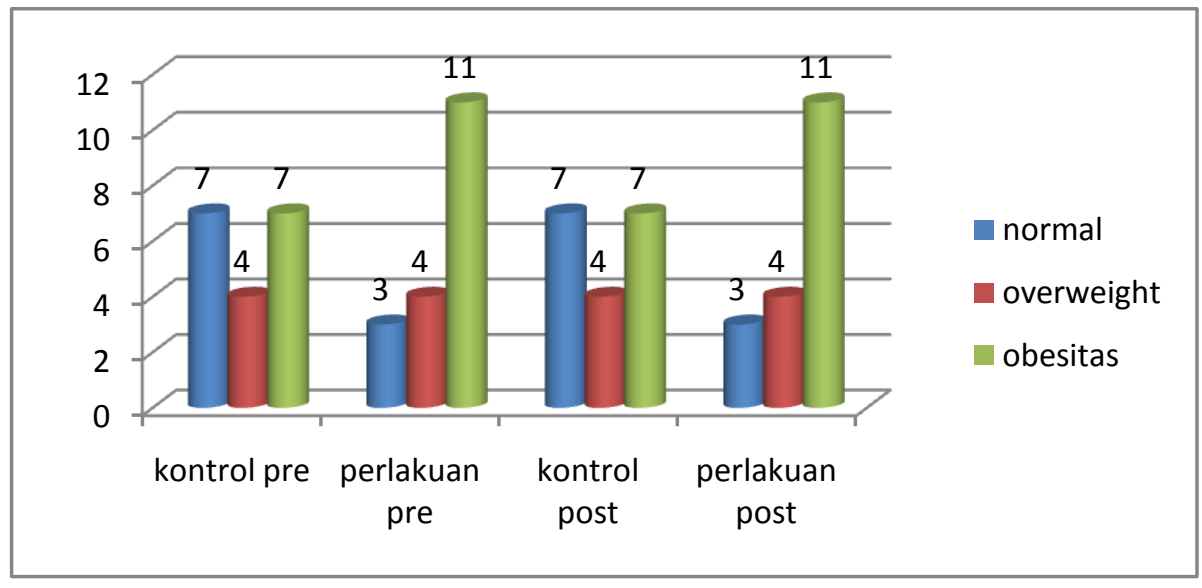

$\mathrm{p}=0.774($ uji paired t-test $)$

Grafik 1. Perbedaan IMT sebelum dan sesudah intervensi 
Grafik 1 menunjukkan tidak ada perubahan IMT sebelum dan sesudah intervensi antara kedua kelompok, dan secara statistik tidak terdapat perbedaan antara IMT sebelum dan sesudah perlakuan pada kelomok kontrol maupun perlakuan $(\mathrm{p}>0.05)$

\section{Perbedaan kadar LDL dan HDL sebelum dan setelah intervensi}

Perbedaan kadar LDL dan HDL subyek sebelum dan setelah intervensi disajikan pada tabel 3.

Tabel 3. Perbedaan kadar LDL dan HDL sebelum dan setelah intervensi

\begin{tabular}{|c|c|c|c|c|c|c|c|}
\hline \multirow[t]{2}{*}{ Kelompok } & $\mathbf{N}$ & $\begin{array}{l}\text { Kadar LDL } \\
\text { pre }(\mathrm{mg} / \mathrm{dl})\end{array}$ & $\begin{array}{l}\text { Kadar LDL } \\
\text { post }(\mathrm{mg} / \mathrm{dl})\end{array}$ & $\mathbf{p}$ & $\begin{array}{l}\text { Kadar HDL pre } \\
(\mathrm{mg} / \mathrm{dl})\end{array}$ & $\begin{array}{l}\text { Kadar HDL } \\
\text { post (mg/dl) }\end{array}$ & $\mathbf{P}$ \\
\hline & & mean \pm SD & mean \pm SD & & mean $\pm S D$ & mean \pm SD & \\
\hline Kontrol & 18 & $148.03 \pm 23.08$ & $157.68 \pm 26.89$ & $0.085^{1}$ & $46.55 \pm 4.87$ & $48.61 \pm 7.97$ & $0.131^{2}$ \\
\hline Perlakuan & 18 & $152.91 \pm 22.94$ & $163.73 \pm 35.47$ & $0.125^{1}$ & $43.11 \pm 7.14$ & $44.05 \pm 10.47$ & $0.798^{2}$ \\
\hline
\end{tabular}

uji paired sample t-test

${ }^{2}$ uji wilcoxon

Pada tabel 3, dapat dilihat bahwa tidak terdapat perbedaan kadar kolesterol LDL dan HDL sebelum dan sesudah intervensi pada kedua kelompok ( $\mathrm{p}>0.05)$.

\section{PEMBAHASAN}

Penelitian ini memiliki karakteristik subyek wanita dislipidemia dan belum mengalami menopause. Sebagian subyek berusia 40-49 tahun, dan secara uji statistik menunjukkan tidak terdapat perbedaan umur pada kelompok kontrol dan perlakuan, sehingga subyek tergolong homogen. Hasil uji statistik menunjukkan terdapat perbedaan status gizi antara kelompok kontrol dan perlakuan $(\mathrm{p}<0.05)$. Rerata subyek pada penelitian ini termasuk ke dalam kategori overweight dan obesitas.

Pemberian angkak $4.8 \mathrm{~g} /$ hari selama 14 hari tidak berpengaruh terhadap kadar kolesterol LDL dan HDL. Hasil uji statistik menunjukkan tidak ada perbedaan perubahan kadar kolesterol LDL dan HDL sebelum dan sesudah intervensi antara kedua kelompok ( $p>0.05$ ).

Monakolin $\mathrm{K}$ yang terkandung dalam angkak bekerja dengan cara menghambat kerja enzim HMG-KoA reduktase. Jika Monakolin K hadir dengan konsentrasi lebih besar dari HMGKoA, maka HMG-KoA akan cenderung berikatan dengan Monakolin K. ${ }^{1}$ Hal ini akan menyebabkan pembentukan asam mevalonat terhambat. Mevalonat akan diubah menjadi molekul dasar isoprene namun, karena terjadi penghambatan HMG-KoA maka isoprene tidak terbentuk dan pembentukan squalen juga tidak terjadi sehingga sintesis kolesterol terhambat. Kolesterol yang terhambat akan menghambat sintesis VLDL dalam hati. Penghambatan sintesis VLDL secara otomatis akan menekan jumlah LDL dalam darah dan LDL yang ditangkap reseptor LDL diubah menjadi HDL sehingga akan meningkat jumlahnya. ${ }^{9,10,12,13}$

Proses pembuatan angkak dalam penelitian ini melalui proses pemanasan. Dalam proses pemanasan terjadi perubahan pigmen angkak menjadi merah kehitaman. Kemasan yang digunakan menggunakan gelas disposable yang terbuat dari mika. Gelas disposable mempunyai struktur yang berongga sehingga dalam kemasan angkak bisa terjadi proses oksidatif. Hal ini bisa menjadi faktor yang dapat mempengaruhi pengurangan zat aktif dalam angkak. Stabilitas kandungan Monakolin K dalam angkak dapat dipengaruhi oleh faktor fisik diantaranya suhu, lama pemanasan, sinar matahari, $\mathrm{pH}$, penyimpanan, lama penyimpanan dan kemasan. Suhu pemasakan yang baik sebaiknya tidak boleh lebih dari $100^{\circ} \mathrm{C}$. Pengaruh lama pemanasan akan menurunkan intensitas pigmen dalam angkak sebanyak $55 \%$ bila dipanaskan dalam waktu 2 jam. ${ }^{14}$ Paparan sinar matahari sangat mempengaruhi pigmen angkak, intensitas pigmen akan mengalami penurunan sebanyak $\pm 20 \%$ setelah 6 jam dan $60 \%$ setelah 24 jam. Pigmen angkak stabil di $\mathrm{pH}$ basa. Penurunan kadar pigmen angkak sudah terjadi pada waktu penyimpanan 1 bulan. Kemasan yang digunakan sebaiknya menggunakan propolinen berlapis alumunium dan gelas, karena struktur alumunium lebih padat sehingga tidak terjadi proses oksidatif yang mengakibatkan menurunnya stabilitas kandungan Monakolin K. ${ }^{14,15}$ Penurunan kadar kolesterol LDL dan peningkatan kadar HDL tidak hanya dipengaruhi oleh konsumsi Monakolin K. Kadar kolesterol LDL dan HDL juga dipengaruhi oleh beberapa faktor yaitu status gizi dan asupan. ${ }^{1,2}$ 
Status gizi merupakan salah satu faktor yang dapat mempengaruhi profil lipid. Subyek penelitian ini rata-rata masuk ke dalam kategori obesitas. Sebaran subyek obesitas banyak ditemukan pada kelompok perlakuan dibandingkan dengan kelompok kontrol. Pada penderita obesitas sering terjadi gangguan metabolisme lipoprotein, sehingga terdapat kecenderungan adanya peningkatan kadar kolesterol. Hal ini dapat menjadi salah satu faktor pengganggu dalam proses penghambatan Monakolin K, reaksi zat ini akan lama berpengaruh terhadap penghambatan HMG-KoA reduktase karena pada obesitas dapat terjadi gangguan regulasi asam lemak yang akan meningkatkan kadar trigliserida dan ester kolesterol. Peningkatan trigliserida yang besar dalam sirkulasi akan meningkatkan kolesterol yang terdapat pada VLDL dan LDL sekunder karena terjadi penumpukan lemak berlebihan didalam tubuh. ${ }^{16,17,18}$

Asupan juga sangat berpengaruh pada profil lipid. Pada kelompok kontrol terdapat perbedaan asupan kolesterol sebelum dan sesudah perlakuan $(\mathrm{p}<0.05)$. Rata-rata asupan kolesterol sebelum $319.41 \mathrm{mg}$ dan sesudah $241.06 \mathrm{mg}$, namun secara anjuran belum sesuai. Anjuran diet rendah kolesterol untuk penyakit jantung dan pembuluh darah yaitu > $200 \mathrm{mg} .{ }^{1}$ Hal ini bisa menjadi salah satu faktor yang menyebabkan tidak terjadi penurunan terhadap kolesterol LDL dan peningkatan HDL pada kelompok kontrol. Asupan serat yang kurang dengan status gizi berlebih sangat erat hubungannya pada perubahan profil lipid. Hasil recall 24 jam menunjukkan asupan serat yang dikonsumsi berasal dari sayur-sayuran dan buah-buahan. Rata-rata subyek mengonsumsi sayur 200 gr/hari, dan buah 250 gr/hari. Rerata asupan serat seluruh subyek sebelum dan selama intervensi baik pada kelompok kontrol dan perlakuan yaitu $11.58 \mathrm{~g}$. Rata-rata asupan serat yang di konsumsi tergolong kurang, asupan ini baru memenuhi $46.32 \%$ dari asupan seharusnya. Anjuran asupan serat sehari-hari menurut American Dietetic Association (ADA), yaitu 20-35 $\mathrm{g} /$ hari atau berdasarkan Dietary Reference Intake (DRI) setara dengan $14 \mathrm{~g} / 1000 \mathrm{kkal} .{ }^{1,19}$ Kebutuhan asupan serat pada orang dewasa untuk menanggulangi kolesterol telah ditetapkan oleh Food and Drug Administration (FDA) yaitu sebanyak minimal $10 \%$ bahan sumber serat dari total diet. ${ }^{20}$ Penelitian yang dilakukan di Amerika Serikat selama 10 tahun dengan subyek penelitian wanita usia 37-64 tahun menunjukkan bahwa wanita yang mengkonsumsi serat rata-rata 29.9 $\mathrm{g} /$ hari memiliki risiko $34 \%$ lebih rendah untuk terkena penyakit jantung dan pembuluh darah dibandingkan dengan kelompok wanita yang ratarata konsumsi seratnya hanya $11.5 \mathrm{~g} /$ hari. $^{21}$

Serat yang terkandung dalam makanan jika dikonsumsi sesuai anjuran dapat menunda pengosogan lambung sehingga rasa kenyang menjadi lebih lama akibatnya asupan kalori menjadi berkurang. Pada saat seperti ini sekresi insulin akan berkurang dan diikuti dengan penghambatan kerja enzim HMG-KoA reduktase sehingga sintesis kolesterol menurun. ${ }^{22}$ Kerja enzim ini distimulasi oleh adanya insulin dan tiroksin tetapi dihambat oleh adanya glucagon. ${ }^{23}$ Serat juga diketahui dapat mengikat asam empedu dan meningkatkan pengeluarannya melalui feses. Garam empedu yang telah terikat pada serat tidak dapat direabsorpsi kembali melalui siklus enterohepatik dan akan disekresi melalui feses, akibatnya terjadi penurunan jumlah garam empedu yang menuju ke hati. Penurunan ini akan meningkatkan pengambilan kolesterol dari darah untuk disintesis kembali menjadi garam empedu yang baru, sehingga terjadi penurunan kadar kolesterol dalam darah. Pengikatan empedu juga dapat merubah senyawa cholic acid menjadi chenodeoxycholic acid yang dapat menghambat kerja enzim HMG-KoA reduktase. ${ }^{22,23,24}$ Penghambatan enzim ini akan menghambat pembentukan mevalonat, isoprene, squalen dan kolesterol. Jika pembentukan kolesterol terhambat maka VLDL tidak akan dihidrolis dan akan menekan LDL dalam darah. ${ }^{9,13}$

\section{KESIMPULAN}

Pemberian angkak (RYR) dengan dosis 4.8 $\mathrm{g} /$ hari selama 14 hari tidak berpengaruh terhadap penurunan LDL dan peningkatan HDL pada wanita dislipidemia secara bermakna. Tidak ada perbedaan penurunan kadar kolesterol LDL dan peningkatan HDL antara kedua kelompok.

\section{UCAPAN TERIMA KASIH}

Rasa terima kasih penulis ucapkan kepada Tuhan Yang Maha Esa, orang tua yang telah membiayai penelitian ini, seluruh responden yang telah ikut berpartisipasi dalam penelitian ini, pembimbing dan para penguji atas bimbingan dan masukan yang membangun, serta berbagai pihak yang telah memberi dukungan dan motivasi dalam penyusunan karya tulis ilmiah ini. 


\section{DAFTAR PUSTAKA}

1. Krummel DA. Medical Nutrition Therapy for Cardiovascular Disease. In : L. Kathleen Mahan, Sylvia Escott-Stump, editors. Krause's Food and Nutrition Therapy. $12^{\text {th }}$ edition. Canada - Saunders Elsevier; 2008.p.833;6.

2. Adam JMF. Dislipidemia. Dalam : Aru.W. Sudoyo, Bambang Setiyohadi, Idrus Alwi, Marcellus Simadibrata K, Siti Setiati, editor. Ilmu Penyakit Dalam Jilid III. Edisi IV. Jakarta-Ilmu Penyakit Dalam Fakultas Kedokteran UI; 2006.p.1926;31.

3. Laine C, Goldmann D. In the Clinic Dyslipidemia. Ann Intern Med ; 2007.

4. Profil Kesehatan Provinsi Jawa Tengah. 2011.

5. Dinas Kesehatan kota Semarang. Rekapitulasi data kesakitan. 2012.

6. Li XM, Shen XH, Duan ZW, Guo SR. Advances on the Pharmalogical Effects of Red Yeast Rice. Chin J Nat Med 2011; 93:161-6.

7. Becker DJ, Gordon RY, Halbert SC, French B, Morris B, Rader DJ. Red Yeast Rice for Dyslipidemia in Statin- Intolerant Patients. Ann Intern Med 2009;150:830-9.

8. Goenarwo E. Pengaruh Pemberian Ekstrak Angkak terhadap Kadar HDL Darah. Unisula 2011. Journal.unisula.ac.id

9. Robert K. Murray, Daryl K. Granner, Victor W. Rodwell. Biokimia Harper. Edisi 27. Jakarta: Buku Kedokteran EGC;2006.

10. Guytan AC, Hall EJ. Metabolisme Lipid. Buku Ajar Fisiologi Kedokteran. Edisi 11. Jakarta : Penerbit Buku Kedokteran EGC; 2007.p.88394.

11. Ratna D. Hatma. Lipid Profile Among Diverse Ethnic Group In Indonesia. Department of Epidemiology, FKM,UI. 2011;43(1):4-11

12. Musselman ME, Pettit RS, Deneski KL. A Review and Update of Red Yeast Rice. J EvidBased Complem N Altern Med. 2012;17:33-9

13. Sareen S. Gropper, Jack L. Smith, James L. Groff. Advance Nutrition and Human Metabolism. $5^{\text {th }}$ edition. Canada : Wadsworth Cengage Learning; 2009.

14. Betty SLJ, Dharma MK, Fardiaz S. Produksi Konsentrat dan Bubuk Pigmen Angkak dari Monascus Purpureus serta Stabilitasnya dalam Penyimpanan. Bul.Teknol dan Industri Pangan. 1997; 8:39-46.

15. Irnia Nurika. Stabilitas Warna Bubuk Pewarna Dari Ekstrak Angkak Terhadap Beberapa Pengaruh Fisika Dan Kimia. Jurnal Teknologi Pertanian .2012;3(1):67-77

16. Suyatna F.D, Tony Handoko. Hipolipidemik dalam : Ganiswarna dkk., editor : Farmakologi dan Terapi. Jakarta : Gaya Baru. 2003;366-68, 374-76.

17. Arisman. Buku Ajar Ilmu Gizi Obesitas, Diabetes Mellitus, dan Dislipidemia Konsep,
Teori dan Penanganan Aplikatif. Jakarta : EGC;2010.1-44

18. Ahmar, H., 2010. Kolesterol. Dalam Tubuh kita, edisi 40/VI/Oktober/2010.

19. Dreher ML. Dietary Fiber Overview. Indiana : Mead Johnson Nutritionals/Bristol-Myers Squibb Company, Evansville.2001.

20. FDA. Health Claim: Fruit, Vegetable and Grain Product that Contain Fiber, Particularly Soluble Fiber, and Risk of Coronary Heart Disease. US Government Printing Office via GPO access. 1999;2(21):130-3.

21. Wolk A, Manson JE, Stampfer MJ,et al. Longterm Intake of Dietary Fiber and Decreased Risk of Coronary Heart Disease among Women. JAMA 1999;281:1998-2004.

22. Lupton JR dan Turner D. Dietary Fiber: in Biochemical and Physiological Aspect of Human Nutrition. WB Sounders Company, London. 2000

23. Koolman J dan Rohm K-H. Atlas Berwarna dan Teks Biokimia. Hipokrates, cetakan I. 2001;168-9,278-9.

24. Clara MK. Serat Makanan dan Peranannya Bagi Kesehatan. Jurnal Gizi dan Pangan. 2006;1(2):45-54 